
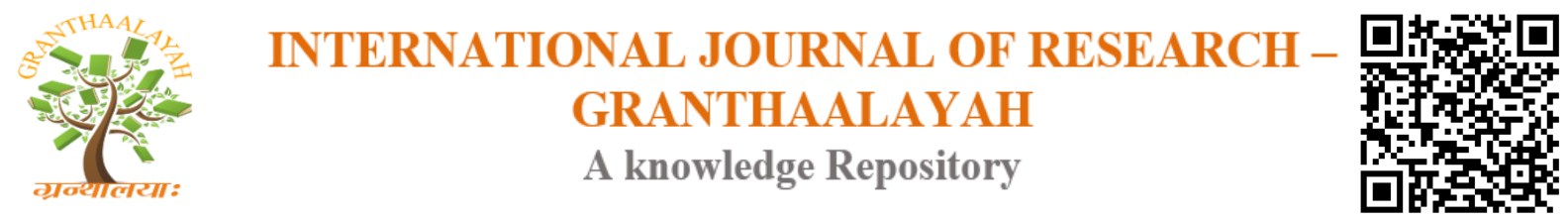

Management

\title{
SECTORAL CONTRIBUTION AND THEIR RELEVANCE IN INDIA: WITH SPECIAL REFERENCE TO THREE SOUTH INDIAN STATES
}

\author{
K. Sivasubramaniyan ${ }^{* 1}$ \\ ${ }^{* 1}$ Associate Professor, Madras Institute of Development Studies, Adyar, Chennai - 600020 , \\ Tamil Nadu, India
}

\begin{abstract}
Majority of the countries in the world has been functioning with its involvement in one or more of the three sectors of the economy such as agriculture, industry and services. In India, a large proportion of population live in poverty due to low level of skill development who are unable to cope with the available employment opportunities in the three sectors of the economy. Proper skill training not only benefits the work force and allows it to earn a decent living, but also contributes to the national economy by enhancing better productivity through the work force. Although India is an agricultural country, its importance in terms of giving employment and to generate adequate income to the people engaged in the sector has been gradually and steadily declining overtime. Consequently, industry and service sectors have been absorbing the displaced agricultural population to some extent. To what extent all the three sectors help the people to get employment and earn income for their livelihood in India, especially in the four southern states of India is discussed in the paper.
\end{abstract}

Keywords: Sectoral Contribution; Skill Development; Economy.

Cite This Article: K. Sivasubramaniyan. (2017). "SECTORAL CONTRIBUTION AND THEIR RELEVANCE IN INDIA: WITH SPECIAL REFERENCE TO THREE SOUTH INDIAN STATES." International Journal of Research - Granthaalayah, 5(9), 116-123. https://doi.org/10.29121/granthaalayah.v5.i9.2017.2211.

\section{Introduction}

Poverty and unemployment contribute to the slow progress of our nation. India's massive population is a threat to sustainable development. Our population has grown from 846 million in 1991 to around 1336 million in August 2017 (Indiaagristat.com) and is still continuing to grow by around 15 million a year. This growth has led to important implications for socio-economic development and for the quality of life in India. The problem of rapidly growing population is reflected in widespread hunger, poverty, unemployment, lack of physical and health infrastructure, increasing scarcity of basic needs such as food, water and shelter in several parts of India despite concerted developmental efforts since independence. According to Global Economic Prospects report (2010), one-fourth of India's population will fall below extreme 
poverty line, less than $\$ 1.25$ a day, by 2025 . The growing population is a major challenge to socio-economic progress and sustainable development. How does one tackle this ever-growing population challenge in India? Although many steps have been taken by the Central and State governments to address this problem, and effective solution has still not yet been reached. In this context, it is considered important to develop skills in order to get suitable employment opportunities, through which the poor can raise their income level for a better living.

\section{Population: The World Scenario}

The world has 242 countries and its population in September 2014 has been 7.143 billion (Table 1) and in August 2017 it is 7.531 billion (Indiaagristat.com). Population of 12 major countries constitute 4.406 billion, which is $61.3 \%$ of World population. Interestingly, 156 countries contribute only 0.372 billion population and each country's population of this category ranging from 56 persons to 1 crore. Table shows that in all 242 countries some form of different sectors related activities have been performed to sustain their economy. What type of sectoral activities to be performed in each country depends upon the country's specific characteristics such as its geographical location and the natural resources endowed and human resources available in the country?

Table 1: World Population of Major Countries as on 6 Sept 2014

\begin{tabular}{|c|c|c|c|c|}
\hline RANK & COUNTRY & $\begin{array}{c}\text { Geographical } \\
\text { Area ('000 } \\
\text { sq. km) } \\
\end{array}$ & $\begin{array}{c}\text { Population } \\
\text { (Crores) }\end{array}$ & $\begin{array}{c}\% \text { of } \\
\text { World } \\
\text { Population }\end{array}$ \\
\hline 1 & \multirow{12}{*}{$\begin{array}{l}\text { China } \\
\text { India } \\
\text { United States } \\
\text { Indonesia } \\
\text { Brazil } \\
\text { Pakistan } \\
\text { Nigeria } \\
\text { Bangladesh } \\
\text { Russia } \\
\text { Japan } \\
\text { Mexico } \\
\text { Philippines }\end{array}$} & 9597 & 136.7 & 19.0 \\
\hline 2 & & 3288 & 124.9 & 17.4 \\
\hline 3 & & 9629 & 31.9 & 4.4 \\
\hline 4 & & 1919 & 25.2 & 3.5 \\
\hline 5 & & 8512 & 20.3 & 2.8 \\
\hline 6 & & 804 & 18.8 & 2.6 \\
\hline 7 & & 924 & 17.9 & 2.5 \\
\hline 8 & & 144 & 15.7 & 2.2 \\
\hline 9 & & 17075 & 14.6 & 2.0 \\
\hline 10 & & 378 & 12.7 & 1.8 \\
\hline 11 & & 1973 & 12.0 & 1.7 \\
\hline \multirow[t]{2}{*}{12} & & 300 & 10.0 & 1.4 \\
\hline & Total & 54542 & 440.6 & 61.3 \\
\hline \multirow[t]{2}{*}{13} & $\begin{array}{l}\text { to } 86 \text { ( } 74 \text { countries) Pop } \\
\text { from } 1 \text { crore to } 10 \text { crores }\end{array}$ & NWO & 236.5 & 32.9 \\
\hline & Total of 86 countries & & 677.1 & 94.2 \\
\hline \multirow[t]{2}{*}{87} & $\begin{array}{l}\text { to } 242 \text { (156 countries) pop } \\
\text { from } 56 \text { to } 1 \text { crore }\end{array}$ & NWO & 37.2 & 5.2 \\
\hline & 1 to 242 countries total & & 714.3 & 99.4 \\
\hline
\end{tabular}

Source: http://en.wikipedia.org/wiki/List_of_countries_by_population (6.9.2014: 9 pm)

Increase of annual population in India is about 10 crores. 
Annual death of population for all causes is about 8 crores.

Annual Net increase of population in India is about two crores. This is equal to the total population available in Sri Lanka ( 2.03 crores). NWO $=$ Not Worked Out Pitcaim Islands under the Control of UK has only 56 population.

As on 15 August 2017: World Population is 752.8 Crore and in India 133.6 Crore.

\section{Sectoral Contribution by Major Countries of the World}

Although each country has to undertake activities of the three sectors, the contribution from each sector varies considerably from one country to another based on its sectoral specialization. For instance, in most of the developed countries the major source of National Income, in terms of Gross National Project (GDP), comes from the service sector followed by industrial sector. In these countries the contribution of agriculture sector is very minimum that is between $<1 \%$ and $5 \%$ of GDP (Table 2). One can notice that in Arabian countries, due to their oil export, a major portion of GDP is derived from the industrial sector. Likewise, the developing countries like China and India their share in agriculture sector to the total GDP has been gradually and steadily declining from about $50 \%$ in the 1950 s to less than $20 \%$ in the 2010 s, indicate their development from primitive agriculture to other sectors. The world's average contribution to GDP has been $5.9 \%, 30.5 \%$ and $63.6 \%$ respectively in agriculture, industry and service sector in 2016 . In most underdeveloped countries their major GDP contribution is only from agriculture. In this context let us examine the GDP contribution in India and three southern states.

Table 2: Nominal GDP sector composition, 2016 (in \% and in millions of

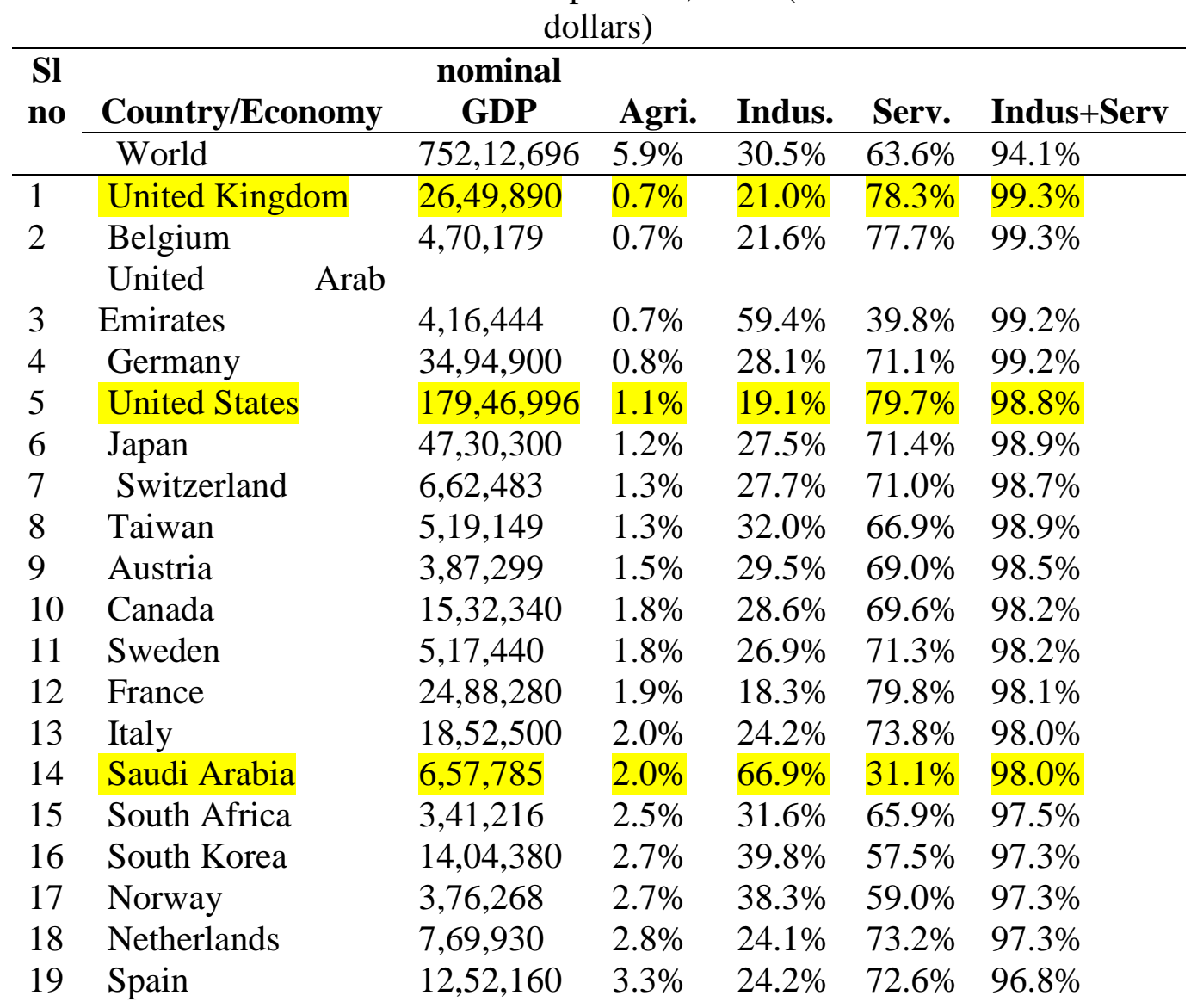




\begin{tabular}{lllllll}
20 & Algeria & $2,46,397$ & $3.3 \%$ & $17.9 \%$ & $78.9 \%$ & $96.8 \%$ \\
21 & Poland & $4,67,350$ & $3.4 \%$ & $33.6 \%$ & $63.0 \%$ & $96.6 \%$ \\
22 & Mexico & $10,63,610$ & $3.7 \%$ & $34.2 \%$ & $62.1 \%$ & $96.3 \%$ \\
23 & Russia & $12,67,750$ & $3.9 \%$ & $36.0 \%$ & $60.1 \%$ & $96.1 \%$ \\
24 & Australia & $12,56,640$ & $4.0 \%$ & $26.6 \%$ & $69.4 \%$ & $96.0 \%$ \\
25 & Denmark & $3,47,196$ & $4.5 \%$ & $19.1 \%$ & $76.4 \%$ & $95.5 \%$ \\
26 & Venezuela & $2,09,226$ & $4.7 \%$ & $34.9 \%$ & $60.4 \%$ & $95.3 \%$ \\
27 & Brazil & $17,69,600$ & $5.4 \%$ & $27.4 \%$ & $67.2 \%$ & $94.6 \%$ \\
28 & China & $112,18,281$ & $8.6 \%$ & $39.8 \%$ & $51.6 \%$ & $91.4 \%$ \\
29 & Turkey & $7,55,716$ & $8.9 \%$ & $28.1 \%$ & $63.0 \%$ & $91.1 \%$ \\
30 & Colombia & $4,00,117$ & $8.9 \%$ & $38.0 \%$ & $53.1 \%$ & $91.1 \%$ \\
31 & India & $22,50,990$ & $17.4 \%$ & $25.8 \%$ & $56.9 \%$ & $82.7 \%$ \\
\hline
\end{tabular}

Source:

https://en.wikipedia.org/wiki/List_of_countries_by_GDP_sector_composition

Note: 1 Dollar $=66.90$ rupees in 2016 (average)

\section{Sectoral Contribution to GDP in India and Three Southern States}

Indian economy is classified in three sectors - Agriculture and allied, Industry and Services. Agriculture sector includes Agriculture (Agriculture proper \& Livestock), Forestry \& Logging, Fishing and related activities. Industry includes 'Mining \& quarrying', Manufacturing (Registered \& Unregistered), Electricity, Gas, Water supply, and Construction. Services sector includes 'Trade, hotels, transport, communication and services related to broadcasting', 'Financial, real estate \& professional services', 'Public Administration, defence and other services'. Services sector is the largest sector of India. Gross Value Added (GVA) at current prices for Services sector is estimated at Rs. 73.79 lakh crore in 2016-17. Services sector accounts for 53.66\% of total India's GVA of 137.51 lakh crore Indian rupees (Table 3). With GVA of Rs. 39.90 lakh crore, Industry sector contributes 29.02\%. While, Agriculture and allied sector shares $17.32 \%$ and GVA is around of Rs. 23.82 lakh crore (GoI, 2017).

Table 3: Gross Value Added (Rupees in Crore) at Current Prices

\begin{tabular}{|l|l|l|l|l|l|l|}
\hline Sector & $\mathbf{2 0 1 1 - 1 2}$ & $\mathbf{2 0 1 2 - 1 3}$ & $\mathbf{2 0 1 3 - 1 4}$ & $\mathbf{2 0 1 4 - 1 5}$ & $\mathbf{2 0 1 5 - 1 6}$ & $\mathbf{2 0 1 6 - 1 7}$ \\
\hline $\begin{array}{l}\text { Agriculture } \\
\text { Sector }\end{array}$ & $15,01,816$ & $16,80,798$ & $19,32,692$ & $20,67,935$ & $21,72,910$ & $23,82,289$ \\
\hline GVA \% & 18.53 & 18.26 & 18.64 & 18.03 & 17.45 & 17.32 \\
\hline Industry Sector & $26,35,052$ & $29,21,262$ & $31,88,270$ & $34,55,221$ & $36,83,358$ & $39,89,791$ \\
\hline GVA \% & 32.50 & 31.73 & 30.76 & 30.12 & 29.58 & 29.02 \\
\hline $\begin{array}{l}\text { Services } \\
\text { Sector }\end{array}$ & $39,69,789$ & $46,03,255$ & $52,45,305$ & $59,47,260$ & $65,95,670$ & $73,78,705$ \\
\hline GVA \% & 48.97 & 50.01 & 50.60 & 51.85 & 52.97 & 53.66 \\
\hline $\begin{array}{l}\text { GVA at } \\
\text { current prices }\end{array}$ & $81,06,657$ & $92,05,315$ & $103,66,267$ & $114,70,416$ & $124,51,938$ & $137,50,785$ \\
\hline GVA \% & 100.00 & 100.00 & 100.00 & 100.00 & 100.00 & 100.00 \\
\hline
\end{tabular}

Source Ministry of Statistics and Programme Implementation, Planning Commission, GOI. 21 March 2017. 


\section{Growth of Service Sector in India - Historical Perspective}

While indicating the present level of contribution of different sectors to the Gross Value Added (GVA) in India it is important to understand how each sector have been contributing to the growth of GDP since Independence. Because only based on the labour and capital investments these growth rates / percentages are possible, so this growth pattern is considered important. Table 4 clearly indicates, since 1950-51 service sector's contribution has been gradually increasing up to 1970s, after that a rapid increase is noticed. Contrary to this pattern, agriculture sector's contribution has been steadily decreasing since the 1950s to till now. Whereas in the industrial sector's GDP contribution is only moderate and it has become stagnant since the 1980s. Since agriculture and industry are inter-related the progressive decline in the growth of agriculture retards the expected growth pattern of industrial sector also. This relationship has to be studied through micro level studies in different states of India. For better understanding of the three sectors' contribution in India from 1950 to 2014 one may refer figure 1.

Table 4: Sector wise Decadal percentage share of GDP in India from 1950-51 to 2013-

14

\begin{tabular}{|l|l|l|l|l|}
\hline Decades & Agriculture & Industry & Services & Total \\
\hline $1950-51$ to $1959-60$ & 47.52 & 15.98 & 36.50 & 100.0 \\
\hline $1960-61$ to $1969-70$ & 42.32 & 19.88 & 37.78 & 100.0 \\
\hline $1970-71$ to $1979-80$ & 38.70 & 22.28 & 38.98 & 100.0 \\
\hline $1980-81$ to $1989-90$ & 31.91 & 25.62 & 42.50 & 100.0 \\
\hline $1990-91$ to $1999-2 \mathrm{~K}$ & 27.37 & 26.19 & 46.40 & 100.0 \\
\hline $2000-01$ to $2009-10$ & 19.73 & 27.32 & 52.95 & 100.0 \\
\hline $2010-11$ to $2013-14$ & 17.95 & 26.34 & 55.71 & 100.0 \\
\hline
\end{tabular}

Source: http://statisticstimes.com/economy/sectorwise-gdpcontribution-of-india.php

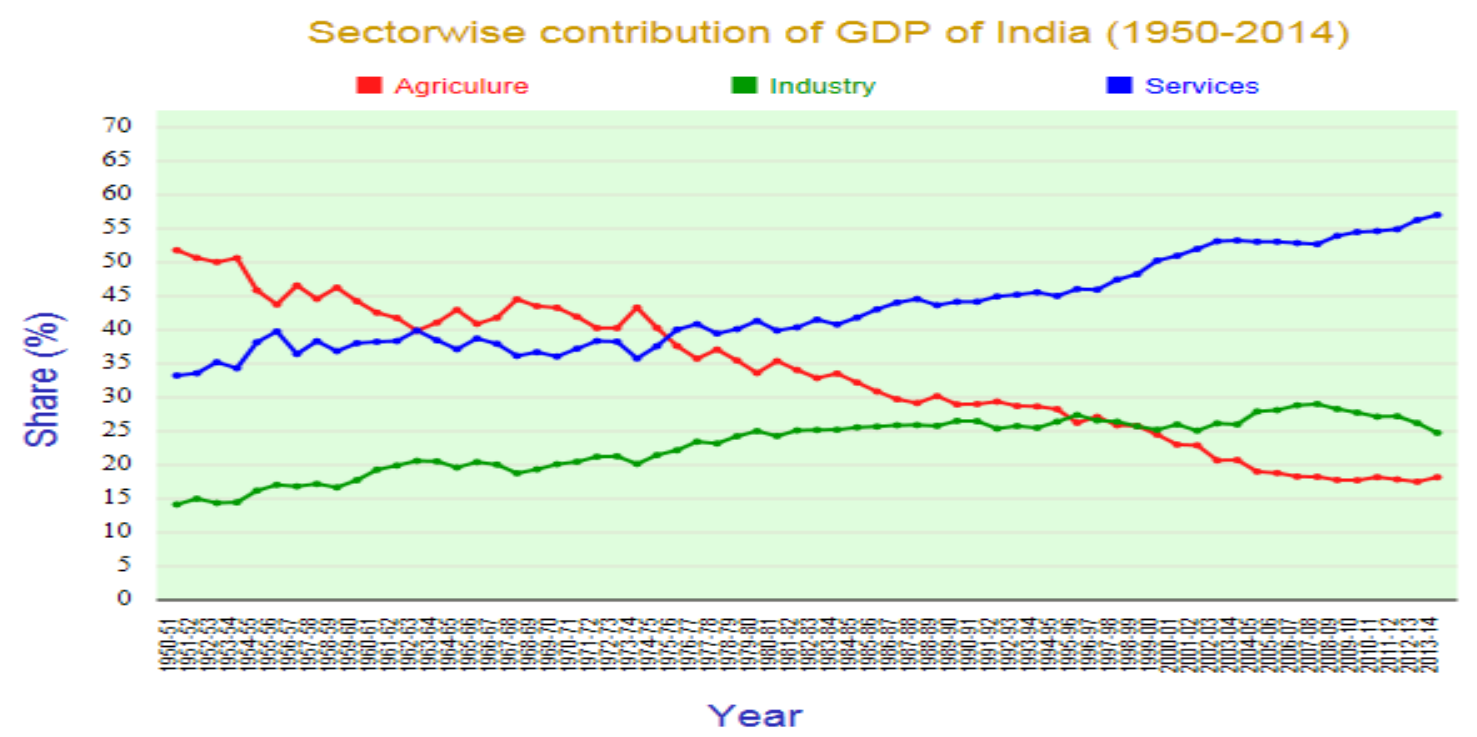

Source: http://statisticstimes.com/economy/sectorwise-gdp-contribution-of-india.php 


\section{Sectoral Contribution by Three Southern States of India}

The overall growth of GDP in India depends upon the contribution made by each state, it is important to study the individual states GDP contribution. For this purpose, the three south Indian States, namely Andhra Pradesh (undivided), Karnataka and Tamil Nadu are taken into account. These three states GDP contribution accounts a little more than a fifth of India's GDP (Table 5).

Table 5: Sector-wise GSDP and Its Percentage Distribution in the Three Southern States of India

\begin{tabular}{|l|l|l|l|l|l|l|}
\hline \multirow{2}{*}{ State } & \multicolumn{3}{|l|}{ Agriculture } & \multicolumn{2}{l|}{ Industry } & \multicolumn{2}{l|}{ Services } \\
\cline { 2 - 7 } & $\mathbf{2 0 1 2 - 1 3}$ & $\mathbf{2 0 1 3 - 1 4}$ & $\mathbf{2 0 1 2 - 1 3}$ & $\mathbf{2 0 1 3 - 1 4}$ & $\mathbf{2 0 1 2 - 1 3}$ & $\mathbf{2 0 1 3 - 1 4}$ \\
\hline $\begin{array}{l}\text { Andhra Pradesh } \\
\text { (undivided) }\end{array}$ & 82048 & 87325 & 105431 & 106801 & 244633 & 261810 \\
\hline $\boldsymbol{\%}$ & $\mathbf{1 9 . 0}$ & $\mathbf{1 9 . 2}$ & $\mathbf{2 4 . 4}$ & $\mathbf{2 3 . 4}$ & $\mathbf{5 6 . 6}$ & $\mathbf{5 7 . 4}$ \\
\hline Karnataka & 39737 & 41151 & 84185 & 85221 & 172737 & 185256 \\
\hline $\boldsymbol{\%}$ & $\mathbf{1 3 . 4}$ & $\mathbf{1 3 . 2}$ & $\mathbf{2 8 . 4}$ & $\mathbf{2 7 . 3}$ & $\mathbf{5 8 . 2}$ & $\mathbf{5 9 . 4}$ \\
\hline Tamil Nadu & 32792 & 35394 & 142927 & 145230 & 275594 & 298352 \\
\hline $\boldsymbol{\%}$ & $\mathbf{7 . 3}$ & $\mathbf{7 . 4}$ & $\mathbf{3 1 . 7}$ & $\mathbf{3 0 . 3}$ & $\mathbf{6 1 . 1}$ & $\mathbf{6 2 . 3}$ \\
\hline India & 764510 & 800548 & 1494921 & 1500225 & 3222680 & 3441017 \\
\hline $\boldsymbol{\%}$ & $\mathbf{1 3 . 9}$ & $\mathbf{1 3 . 9}$ & $\mathbf{2 7 . 3}$ & $\mathbf{2 6 . 1}$ & $\mathbf{5 8 . 8}$ & $\mathbf{5 9 . 9}$ \\
\hline Three States total & 154577 & 163870 & 332543 & 337252 & 692964 & 745418 \\
\hline $\begin{array}{l}\text { \% of 3 states } \\
\text { GSDP to All-India } \\
\text { GDP }\end{array}$ & $\mathbf{2 0 . 2}$ & $\mathbf{2 0 . 5}$ & $\mathbf{2 2 . 2}$ & $\mathbf{2 2 . 5}$ & $\mathbf{2 1 . 5}$ & $\mathbf{2 1 . 7}$ \\
\hline
\end{tabular}

Source: Planning Commission, GOI. 14-12-2014.

http://statisticstimes.com/economy/sectorwise-gdp-of-indian-states.php

One may observe from table 5, agriculture sector's GSDP is relatively more in Andhra Pradesh followed by Karnataka, whereas Tamil Nadu's contribution goes down to a single digit of about $7 \%$. The services sector's GSDP contribution in the states is moving on a reverse direction, where Tamil Nadu ranks first followed by Karnataka and Andhra Pradesh. Compared to Services sector, the industrial sectors growth performance in all these states are not appreciable. However, one can think when that agriculture's GSDP contribution is steadily declining it impact may be seen first in the upward growth of services sector followed by industrial sector. This aspect has to be studied in depth in the context of other states of India.

\section{Gross State Domestic Product Trend in Tamil Nadu since the 1960s}

Tamil Nadu is one of the leading states in India in the development process especially in services and industrial sectors activities. Hence the state's GSDP analysis assumes importance. Agriculture development in a state basically depends upon its water resources since agricultural productivity is three to five times more under irrigated condition compared to rainfed cultivation. Since water resources position at the present situation is very weak in Tamil Nadu, its contribution in terms of GSDP is also declining considerably compared to other states. 
Table 6 shows that agriculture sector's contribution to Gross State Domestic Product has gradually and steadily declined from $43.5 \%$ in $1960-61$ to about $7 \%$ in 2013-14. Industrial sector's contribution was growing up to 1980-81 and after that stagnated with $33 \%$ up to 199091 and afterwards, it marginally declined. Whereas the service sector's contribution was indeed marvelous, steady and gradual. These observations indicate that prosperity in the primary sector (through employment generation) may be possible, only if enough attention is paid to regain its contribution or at least stop the trend of decline in Tamil Nadu.

Table 6: Structural Changes in the Economy of Tamil Nadu (GSDP Contribution in $\%)$

\begin{tabular}{|l|l|l|l|l|l|l|l|}
\hline Sl. no & Sectors & $\mathbf{1 9 6 0 - 1}$ & $\mathbf{1 9 7 0 - 1}$ & $\mathbf{1 9 8 0 - 1}$ & $\mathbf{1 9 9 0 - 1}$ & $\mathbf{1 9 9 9 - 2 K}$ & $\mathbf{2 0 1 3 - 4}$ \\
\hline 1 & $\begin{array}{l}\text { Agriculture } \\
\text { \& Allied }\end{array}$ & 43.5 & 34.8 & 25.9 & 23.4 & 17.3 & 7.4 \\
\hline 2 & Industry & 20.3 & 26.9 & 33.5 & 33.1 & 29.6 & 30.3 \\
\hline 3 & Services & 36.2 & 38.3 & 40.6 & 43.5 & 53.1 & 62.3 \\
\hline & Total & 100.0 & 100.0 & 100.0 & 100.0 & 100.0 & 100.0 \\
\hline
\end{tabular}

Source: GoTN, Tamil Nadu an Economic Appraisal, Various issues, DEAR, Chennai.

Since the primary sector's income contribution has been declining, the effect of employment generation - in terms of percentage decline during 1993-94 to 2004-05 - also indicates the same declining trend, which is roughly $-6 \%$ between 1993-4 and 1999-2000 and further to -12\% between 1999-2000 and 2004-05 (Table 7).

Table 7: Sector wise Employment Status in Tamil Nadu

\begin{tabular}{|l|l|l|l|l|l|l|l|l|l|}
\hline \multirow{2}{*}{$\begin{array}{l}\text { Sl. Sector } \\
\text { no }\end{array}$} & \multicolumn{6}{|c|}{ Employment in Lakhs } & \multicolumn{2}{c|}{ Change between } \\
\cline { 2 - 10 } & $\begin{array}{l}1993- \\
94\end{array}$ & $\%$ & $\begin{array}{l}1999- \\
2000\end{array}$ & $\%$ & $\begin{array}{l}2004- \\
05\end{array}$ & $\begin{array}{l}\text { Col 3 \& } \\
\text { Col 5 }\end{array}$ & $\begin{array}{l}\text { Col 5 \& } \\
\text { Col 7 }\end{array}$ \\
\hline 1 & 2 & 3 & 4 & 5 & 6 & 7 & 8 & 9 & 10 \\
\hline 1 & $\begin{array}{l}\text { Agriculture } \\
\text { \& Allied }\end{array}$ & 154.82 & 54.2 & 145.7 & 50.3 & 127.8 & 41.6 & -6 & -12 \\
\hline 2 & Industry & 62.43 & 21.9 & 68.5 & 23.6 & 85.1 & 27.7 & 10 & 24 \\
\hline 3 & Services & 68.36 & 23.9 & 75.5 & 26.1 & 94.4 & 30.7 & 10 & 25 \\
\hline & $\begin{array}{l}\text { Total } \\
\text { Employment }\end{array}$ & 285.6 & 100.0 & 289.7 & 100.0 & 307.3 & 100.0 & 1 & 6 \\
\hline
\end{tabular}

Source: GoTN, Tamil Nadu an Economic Appraisal, Various issues, DEAR, Chennai.

However, the contribution from the other two sectors are progressing and employment generation is also positive, which is between $22 \%$ and $31 \%$ in each of the two sectors. Despite this, the fact remains that in absolute terms, employment levels in the primary sector is higher in comparison with the other two sectors. Therefore it is both necessary and important to foster the primary sector to generate employment. To this end various aspects need to be considered to uplift this sector in all the three states under study. 


\section{Concluding Observations}

The world has made up of about 240 countries and in each country at least any one of the three sectors such as agriculture, industry and services is established based on the geographical location of the country to run the economy of the nation. Such that India has all the three sectors of the economy but each sector's contribution to the GDP varies considerably depending upon individual states contribution to the nation. Likewise, the three south Indian States - Andhra Pradesh, Karnataka and Tamil Nadu - also follow the pattern of India and the three states contribution to the national GDP is a little more $20 \%$ in each sector.

The analysis of sectoral contribution in Tamil Nadu in the past 60 years shows that agriculture sector's contribution has been gradually and steadily declining whereas the services sector is improving continuously and the industrial sector is to some extent stagnated over this period, except marginal improvements in a few decades. The employment scenario in the three sectors indicate still agriculture sector provides major share of employment compared to the other two sectors. This is true in Andhra Pradesh followed by Karnataka and Tamil Nadu. Hence preference should be given to foster agriculture and related rural development aspects to strengthen the economy. Population control especially in Indian context is most important since ratio of effective population (in terms of education and employment) to total population in India is much less that hinders the growth of the country. Altogether, the three sectors only have possessed the total population of the country, hence due importance to be given to improve all the three sectors not only in India but also throughout the world.

\section{References}

[1] https://www.Indiaagristat.com

[2] Global Economic Prospects Report 2010: (https://www.ibtimes/articles/27804/20100610 /globaleconomy-world-bank-economy-recovery-debt-cricis.htm)

[3] https://en.wikipedia.org/wiki/List_of_countries_by_population

[4] https://en.wikipedia.org/wiki/List_of_countries_by_GDP_sector_composition

[5] Ministry of Statistics and Programme Implementation, Planning Commission, GOI. 21 March 2017.

[6] http://statisticstimes.com/economy/sectorwise-gdp-contribution-of-india.php

[7] Source: GoTN, Tamil Nadu an Economic Appraisal, Various issues, DEAR, Chennai.

*Corresponding author.

E-mail address: ksivam2010@ gmail.com 